\title{
Carbon 14 transfer from seawater to the atmosphere through degassing processes in the Bay of Seine (North-West of France)
}

\author{
M. Fontugne ${ }^{1}$, D. Maro², L. Tenailleau ${ }^{3}$, P. Germain ${ }^{2}$, D. Hébert ${ }^{2}$, M. Rozet ${ }^{2}$, \\ C. Noury ${ }^{1}$, C. Hatté ${ }^{1}$ and M. Paterne ${ }^{1}$ \\ ${ }^{1}$ Laboratoire des Sciences du Climat et de l'Environnement, UMR 1572-CEA/CNRS, \\ Domaine du CNRS, 91198 Gif-sur-Yvette, France \\ ${ }^{2}$ Institut de Radioprotection et de Sûreté Nucléaire, Laboratoire de Radioécologie de \\ Cherbourg-Octeville, 50130 Cherbourg-Octeville, France \\ ${ }^{3}$ Marine Nationale, Groupe d'Études Atomiques, BP. 34, 50115 Cherbourg Naval, France
}

\begin{abstract}
COGEMA La Hague nuclear reprocessing plant is located in the North West of Cotentin peninsula near Cherbourg (France). This nuclear plant releases radioelements in atmosphere and in the English Channel. About 8.5 TBq.year ${ }^{-1}$ of radiocarbon are released as the liquid wastes through a pipe a few kilometres off sea shore, West of the reprocessing plant. Recent studies in the peninsula show anomalous higher radiocarbon contents in vegetation near the coast that have suggested a supplementary marine contribution through the degassing of the ${ }^{14} \mathrm{C}$ excess supplied by liquid releases of the nuclear plant. Carbon dioxide partial pressure, ${ }^{14} \mathrm{C}$ activities were measured in air and sea water in the Bay of Seine and around the COGEMA-La Hague nuclear reprocessing plant during three cruises in 2000 and 2002. Results show clearly that sea is a source of $\mathrm{CO}_{2}$ and ${ }^{14} \mathrm{C}$ to the atmosphere. Higher ${ }^{14} \mathrm{C}$ concentrations in air and water related to the La Hague liquid wastes are clearly recorded. The aim of this paper is to show results of these oceanographic campaigns. Flux between seawater and atmosphere are calculated in the NorthWest Cotentin and in Bay of Seine.
\end{abstract}

\section{INTRODUCTION}

COGEMA La Hague nuclear reprocessing plant is located in the north west of Cotentin peninsula near Cherbourg (France). This nuclear plant releases radio-elements in atmosphere and in the English Channel. Radiocarbon is released to the environment as $\mathrm{CO}_{2}$ through a 100 metres high chimney and as liquid waste few kilometres off sea shore, west of the reprocessing plant. Atmospheric ${ }^{14} \mathrm{C}$ releases are estimated to 19 TBq.year ${ }^{-1}[1]$.

The carbon dioxide is assimilated by plants through photosynthetic processes. Consequently, the ${ }^{14} \mathrm{C}$ activity of vegetation constitute an integrated record of COGEMA La Hague emissions, during the vegetative period (spring to fall). During 3 years $(1997,1998$ and 1999$){ }^{14} \mathrm{C}$ measurements in air and in furzes were performed. Measurements of ${ }^{14} \mathrm{C}$ activity in the chimney plume show a rapid dilution from about $7200 \mathrm{~Bq} \cdot \mathrm{kg}^{-1} \mathrm{C}$ near the chimney to values ranging between 400 and $900 \mathrm{~Bq} \cdot \mathrm{kg}^{-1} \mathrm{C}$ at a distance of 4 to $6 \mathrm{~km}[2]$. Outside periods of release ${ }^{14} \mathrm{C}$ residual value is around $270 \mathrm{Bqkg}^{-1} \mathrm{C}_{\text {. }}$ Vegetation around the nuclear plant record these period of release, concentration in bio-indicators like furzes ranging between once and twice the present atmospheric background [2] [3]. Higher ${ }^{14} \mathrm{C}$ concentrations are observed at the coast suggesting a supplementary marine contribution though the degassing of the ${ }^{14} \mathrm{C}$ excess supplied by liquid release (8.5 TBq.year $\left.{ }^{-1}\right)$ through a pipe few kilometres off sea shore, west of the reprocessing plant [1].

The aim of this study is to estimate the ${ }^{14} \mathrm{C}$ fluxes between seawater and atmosphere in the north-west Cotentin and in the Bay of Seine. 


\section{EQUIPMENT AND METHOD}

\subsection{Strategy}

In order to estimate ${ }^{14} \mathrm{CO}_{2}$ fluxes across the sea surface water and the atmosphere interface the partial pressure of carbon dioxide $\left(\mathrm{pCO}_{2}\right)$ were calculated using measurement of total alkalinity and $\mathrm{pH}$ of water. According to Henry's law the difference between $\mathrm{pCO}_{2}$ in air and water indicates if seawater is a source of $\mathrm{CO}_{2}$ to the atmosphere. Carbon dioxide fluxes were calculated following equation (1).

$$
\Phi\left(\mathrm{CO}_{2}\right)\left(\text { mole. } \mathrm{m}^{-2} \cdot \mathrm{s}^{-1}\right)=\mathrm{K} \text {. S. } \Delta \mathrm{pCO}_{2}
$$

$\mathrm{K}\left(\mathrm{m} . \mathrm{s}^{-1}\right)$ is the $\mathrm{CO}_{2}$ transfer coefficient between seawater and atmosphere, $\mathrm{S}$ is solubility of $\mathrm{CO}_{2}$ $\left(\right.$ mole. $\left.\mathrm{m}^{-3} \cdot \mathrm{atm}^{-1}\right)$ and $\Delta \mathrm{pCO}_{2}(\mathrm{~atm})$ is the difference between partial pressure in water and air. $\mathrm{pCO}_{2}$ in air was considered as constant mean value of $367 \mu$ atm [4] [5] [6] [7]. $\mathrm{K}$ is a parameter depending on wind speed and has been calculated by using studies of Liss and Merlivat [8], Tans et al., [9] and Wanninkhof and McGillis [10]. As these $\mathrm{K}$ values are slightly different in these three studies we present the three $\mathrm{CO}_{2}$ flux estimates.

The exchange of $\mathrm{CO}_{2}$ between the atmosphere and the surface ocean is an equilibrium process, and the nett $\mathrm{CO}_{2}$ flux is the difference between gas going from water to air and gas going from air to water. Both these fluxes carry ${ }^{14} \mathrm{C}$ at concentrations appropriate to the medium from where they originate, and the nett ${ }^{14} \mathrm{C}$ flux is, once again, the difference. The expression for the nett ${ }^{14} \mathrm{C}$ flux from surface ocean to the atmosphere should be of the form (equation 2).

$$
\Phi\left({ }^{14} \mathrm{C}\right)=\left[{ }^{14} \mathrm{C}\right]_{\mathrm{O}} \Phi_{\mathrm{OA}}\left(\mathrm{CO}_{2}\right)-\left[{ }^{14} \mathrm{C}\right]_{\mathrm{A}} \Phi_{\mathrm{AO}}\left(\mathrm{CO}_{2}\right)
$$

Regarding constant factor due to appropriate units use, ${ }^{14} \mathrm{C}$ fluxes were calculated following equation (3).

$$
\Phi\left({ }^{14} \mathrm{C}\right)\left(\mathrm{Bq} \cdot \mathrm{km}^{-2} \cdot \mathrm{d}^{-1}\right)=10^{9}\left(\left[{ }^{14} \mathrm{C}\right]_{\mathrm{O}} \cdot \Phi_{\mathrm{OA}}-\left[{ }^{14} \mathrm{C}\right]_{\mathrm{A}} \Phi_{\mathrm{AO}}\right)
$$

where $\left[{ }^{14} \mathrm{C}\right]_{\mathrm{O}}$ and $\left[{ }^{14} \mathrm{C}\right]_{\mathrm{A}}$ are the ${ }^{14} \mathrm{C}$ concentrations $\left(\mathrm{Bq} \cdot \mathrm{Kg}^{-1} \mathrm{C}\right)$ in the surface ocean and air, respectively, and $\Phi_{\mathrm{OA}}$ and $\Phi_{\mathrm{AO}}$ are the $\mathrm{CO}_{2}$ fluxes $\left(\right.$ mole. $\left.\mathrm{m}^{-2} \cdot \mathrm{s}^{-1}\right)$ from ocean to air, and air to ocean, respectively.

This method usable if the samples are collected out of the influence of the chimney plume which is easily detectable by the krypton $85\left({ }^{85} \mathrm{Kr}\right)$ content. During ${ }^{14} \mathrm{C}$ sampling ${ }^{85} \mathrm{Kr}$ was measured continuously at a frequency of 1 measurement. $\mathrm{s}^{-1}$ [11]. Consequently the detection of ${ }^{85} \mathrm{Kr}$ emitted from the chimney of the reprocessing plant allows air to be sampled for ${ }^{14} \mathrm{C}$ measurements free of direct contamination coming from the plume of the chimney.

\subsection{Techniques}

Sea water and air samples were collected simultaneously during two cruises (TRANSAT 1 cruise, February $24-28^{\text {th }}, 2002$ and TRANSAT 2 cruises, August $27-31^{\text {st }}, 2002$ ) around north Cotentin peninsula and Bay of Seine (figure 1).

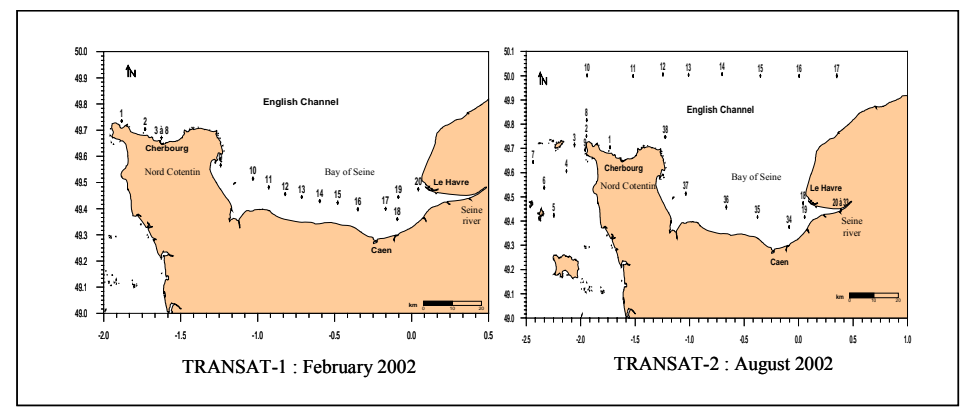

Figure 1. Location of sampling stations during TRANSAT 1 and TRANSAT 2. 
Temperature and salinity of seawater were measured using a SBE 19-03 Seabird equipment and wind direction and speed were recorded. Only for TRANSAT cruises, $\mathrm{CO}_{2}$ partial pressure in surface sea water were calculated using $\mathrm{pH}$ and total alkalinity measurements following "Standard Operating Procedures SOP3 and SOP6" of the US Department of Energy [12].

${ }^{14} \mathrm{C}$ activity in air samples were determined using the procedure defined by Maro et al., [13].

Water samples were collected in glass bottle and poisoned with mercury chloride. In the laboratory, total $\mathrm{CO}_{2}\left(\Sigma \mathrm{CO}_{2}\right)$ was extracted from seawater following the procedure described by Bard et al., [14] and Leboucher et al., [15].

The radiocarbon activity was measured at Laboratoire de Sciences du Climat et de l'Environnement using the Gif Accelerator Mass Spectrometry (AMS) facilities. Results are expressed in $\mathrm{Bq}^{-\mathrm{kg}^{-1} \mathrm{C}}$ $\left(100 \mathrm{pMC}\right.$ is equivalent to $\left.226 \mathrm{~Bq} \cdot \mathrm{kg}^{-1} \mathrm{C}\right)$. The relative precision varies between 0.5 and $2 \%$.

\section{RESULTS AND DISCUSSION}

Results are presented in table 1.

Table 1. Distance from the pipe outlet, wind speed at $10 \mathrm{~m}$ high, surface seawater temperature (SST), salinity and $\mathrm{CO}_{2}$ partial pressure in sea surface seawater, ${ }^{14} \mathrm{C}$ activity in seawater and air, during TRANSAT cruises.

\begin{tabular}{|c|c|c|c|c|c|c|c|}
\hline $\begin{array}{c}\text { Station } \\
\text { TRANSAT } 1\end{array}$ & $\begin{array}{l}\text { Distance } \\
\text { (km) }\end{array}$ & $\begin{array}{l}\text { Wind speed } \\
(\mathrm{m} / \mathrm{s})\end{array}$ & $\begin{array}{l}\text { SST } \\
\left({ }^{\circ} \mathrm{C}\right)\end{array}$ & $\begin{array}{l}\text { Salinity } \\
\text { (pm) }\end{array}$ & $\begin{array}{c}\text { pCO2 } \\
\text { (patm) }\end{array}$ & $\begin{array}{c}\text { [14C]water } \\
\text { (Bq/kg C) }\end{array}$ & $\begin{array}{c}\text { [14C]air } \\
(\mathrm{Bq} / \mathrm{kg} \mathrm{C})\end{array}$ \\
\hline 1 & 15 & 12 & 9.7 & 33.91 & 373.4 & 587.8 & 238.8 \\
\hline 2 & 22 & 11 & 9.8 & 33.86 & 378.6 & & \\
\hline 3 & 29 & 12 & 9.5 & 33.49 & 377.1 & 410.2 & 239.4 \\
\hline 4 & 30 & 11 & 9.5 & 33.61 & 386.3 & & \\
\hline 5 & 30 & 10 & 9.6 & 33.55 & 384.1 & & \\
\hline 6 & 30 & 10 & 9.6 & 33.42 & 386 & & \\
\hline 8 & 30 & 10 & 9.6 & 33.63 & 373.5 & & \\
\hline 9 & 58 & 8 & 8.7 & 33.01 & 387.5 & 378.4 & 237.1 \\
\hline 10 & 74 & 12 & 9.2 & 33.43 & 378.5 & 379.5 & 239.3 \\
\hline 11 & 82 & 9 & 8.8 & 33.05 & 402.8 & & \\
\hline 12 & 91 & 9 & 8.7 & 32.88 & 400.7 & 353.3 & 236.4 \\
\hline 13 & 99 & 9 & 8.6 & 32.41 & 416.8 & & \\
\hline 14 & 107 & 10 & 8.5 & 32.35 & 415.3 & 331.0 & 236.2 \\
\hline 15 & 115 & 10 & 8.5 & 32.31 & 419.9 & & \\
\hline 16 & 125 & 10 & 8.5 & 32.17 & 430.3 & 324.8 & 241.3 \\
\hline 17 & 138 & 10 & 8.5 & 32.37 & 421 & & \\
\hline 18 & 144 & 10 & 8.4 & 31.26 & 441.2 & & 242.7 \\
\hline 19 & 143 & 10 & 8.4 & 31.65 & 448.6 & & \\
\hline 20 & 151 & 10 & 8.1 & 25.63 & 613.6 & 286.3 & 236.2 \\
\hline \multicolumn{8}{|l|}{ Station } \\
\hline TRANSAT 2 & $\begin{array}{c}\text { Distance } \\
(\mathbf{k m})\end{array}$ & $\begin{array}{c}\text { Wind speed } \\
(\mathrm{m} / \mathrm{s})\end{array}$ & $\begin{array}{l}\text { SST } \\
\left({ }^{\circ} \mathrm{C}\right)\end{array}$ & $\begin{array}{c}\text { Salinity } \\
\text { (pm) }\end{array}$ & $\begin{array}{c}\text { pCO2 } \\
\text { (patm) }\end{array}$ & $\begin{array}{c}\text { [14C] water } \\
(\mathrm{Bq} / \mathrm{kg} \mathrm{C})\end{array}$ & $\begin{array}{l}{[14 \mathrm{C}] \text { air }} \\
\text { (Bq/kg C) }\end{array}$ \\
\hline 1 & 22.40 & 7.3 & 17.9 & 34.78 & 465.7 & 342.5 & 226.4 \\
\hline 5 & 33.7 & 6.2 & 18.0 & 35.10 & 422.7 & 270.7 & 222.2 \\
\hline 7 & 34.4 & 3.4 & 16.7 & 35.10 & 424.0 & & \\
\hline 9 & 3.6 & 3.4 & 17.8 & 34.89 & 462.9 & 706.7 & 346.4 \\
\hline 10 & 37.7 & 4.1 & 17.1 & 35.06 & 438.0 & 281.6 & 240.9 \\
\hline 13 & 83.4 & 3.4 & 17.7 & 34.90 & 442.5 & & \\
\hline 17 & 175.4 & 1.8 & 18.6 & 34.56 & 452.0 & 343.6 & 262.6 \\
\hline 18 & 151.3 & 3.1 & 19.6 & 29.01 & 759.0 & 258.3 & 243.5 \\
\hline 19 & 152.7 & 3.9 & 19.5 & 22.40 & 1407.6 & & \\
\hline 34 & 144.4 & 5.5 & 19.4 & 31.66 & 464.3 & & \\
\hline 36 & 101.7 & 4.8 & 19.6 & 33.30 & 402.0 & & \\
\hline 37 & 74.0 & 4.6 & 18.7 & 34.35 & 441.0 & 351.5 & 262.2 \\
\hline
\end{tabular}




\section{$3.1 \mathrm{pCO}_{2}$ and ${ }^{14} \mathrm{C}$ activities}

$\mathrm{pCO}_{2}$ values vary from 373 to $614 \mu \mathrm{atm}$ for the TRANSAT 1 cruise data, and between 402 and $1408 \mu \mathrm{atm}$ for TRANSAT 2 cruise data. $\mathrm{pCO}_{2}$ measurements in water show similar high values compared to air during the winter and summer cruises and increase toward Seine River estuary. This indicates $\mathrm{CO}_{2}$ flux to the atmosphere since mean atmospheric $\mathrm{pCO}_{2}$ value is $367 \mu \mathrm{atm}$. This results are easily predictable because coastal and shelf and estuarine areas exhibit high biological activity due to the nutrient input near the river mouths and organic matter recycling in the water column [16]. This heterotrophic activity resulting in high degradation rates at the sediment surface and in the water column produces high dissolved $\mathrm{CO}_{2}$ concentrations [17].

During TRANSAT cruises, ${ }^{14} \mathrm{C}$ activities in surface water vary between 258.3 to $706.7 \mathrm{~Bq} \cdot \mathrm{kg}^{-1} \mathrm{C}$. The highest value corresponds to a station within the plume of the liquid waste near the pipe outlet. All these values are higher than the reference value, 239 Bq. kg ${ }^{-1}$ C (year 2002). During TRANSAT 1 winter cruise atmospheric values are near the reference value mainly due to the stormy meteorological conditions that induce a greater mixing of the atmosphere. During the TRANSAT 2 summer cruise, ${ }^{14} \mathrm{C}$ activities in air present a positive correlation with ${ }^{14} \mathrm{C}$ in surface water, confirming previous results [3][13] and the transfer from the sea.

\subsection{Carbon dioxide and ${ }^{14} \mathrm{C}$ fluxes}

\subsubsection{TRANSAT 1}

$\mathrm{CO}_{2}$ fluxes to the atmosphere are calculated from equation 1 using $\mathrm{K}$ transfer coefficient given in literature [8] [9] [10]. Carbon fluxes range between few to $911 \mathrm{~kg} \mathrm{C} . \mathrm{km}^{-2} . \mathrm{d}^{-1}$ (figure 2a). For the high $\mathrm{pCO}_{2}$ value in seawater, the difference between estimates is high nevertheless the relative differences are constants for high and low water $\mathrm{pCO}_{2}$ values.

As ${ }^{14} \mathrm{C}$ fluxes given by equation 3 are proportional to the carbon dioxide fluxes we observe similar difference between estimates (figure 2b). During TRANSAT 1 , the highest ${ }^{14} \mathrm{C}$ flux is encountered near Cherbourg City and the lowest between Cherbourg city and the Seine river estuary. Maximum flux are $6.410^{5} \mathrm{~Bq} \cdot \mathrm{km}^{-2} \cdot \mathrm{d}^{-1}$ for TRANSAT 1.

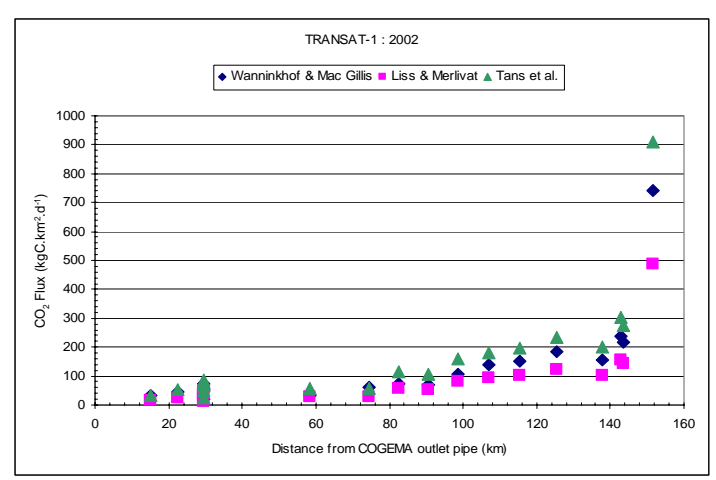

a)

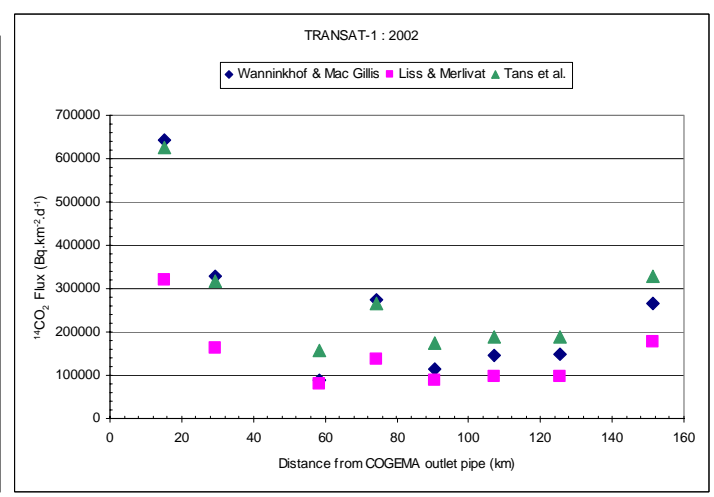

b)

Figure 2. Variations $\mathrm{CO}_{2}$ fluxes (a) and ${ }^{14} \mathrm{C}$ fluxes (b) in surface seawater versus distance from pipe outlet during TRANSAT 1. 


\subsubsection{TRANSAT 2}

Carbon fluxes range between few to $493 \mathrm{~kg} \mathrm{C} . \mathrm{km}^{-2} \cdot \mathrm{d}^{-1}$ (figure 3a).

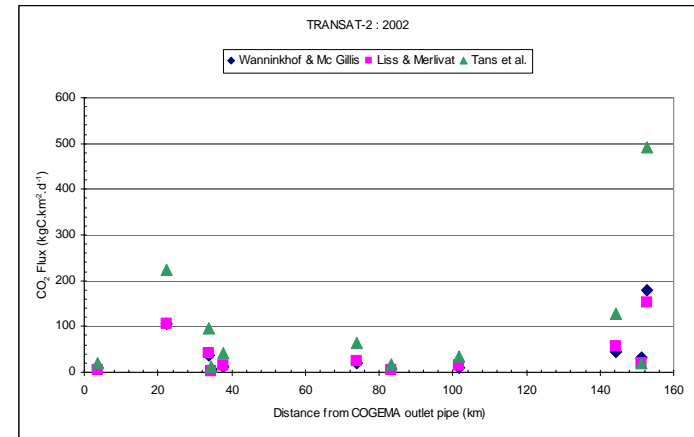

a)

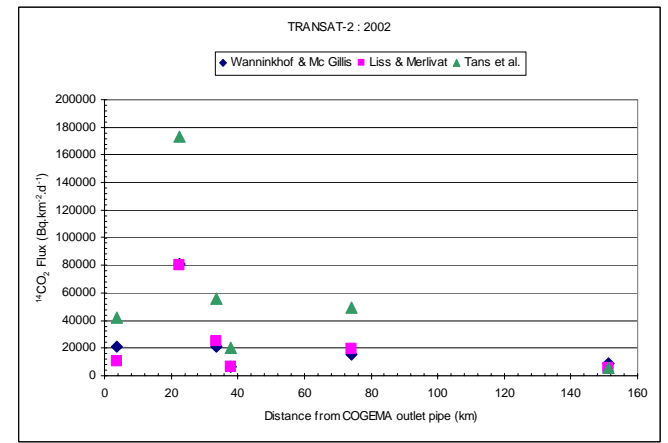

b)

Figure 3. Variations $\mathrm{CO}_{2}$ fluxes (a) and ${ }^{14} \mathrm{C}$ fluxes (b) in surface seawater versus distance from pipe outlet during TRANSAT 2 .

Although water $\mathrm{pCO}_{2}$ are higher during this cruise the carbon dioxide fluxes are smaller due to the weak wind speed. During this cruise maximum ${ }^{14} \mathrm{C}$ fluxes values were encountered near Cherbourg city and minimum values near Seine river estuary (figure 3b). Maximum flux are $1.710^{5} \mathrm{~Bq} \cdot \mathrm{km}^{-2} \cdot \mathrm{d}^{-1}$ for TRANSAT 2.

\subsubsection{Annual flux estimate for the Bay of Seine}

Following estimates derived from Tans et al. model, the mean flux in the Bay of Seine due to COGEMA La Hague liquid wastes would reach $2.310^{5}$ and $3.910^{4} \mathrm{~Bq} \cdot \mathrm{km}^{-2} \cdot \mathrm{d}^{-1}$ for TRANSAT 1 and 2 respectively. A rough annual estimation would give $216 \mathrm{GBq}$ for the $4400 \mathrm{~km}^{-2}$ of the Bay of Seine, representing less than $3 \%$ of the liquid release from COGEMA La Hague nuclear reprocessing plant.

\section{CONCLUSION}

Simultaneous measurements of $\mathrm{CO}_{2}$ partial pressure and ${ }^{14} \mathrm{C}$ activity in air and sea water indicate that the English Channel and Bay of Seine are a source a carbon dioxide to the atmosphere in good agreement with previous studies. ${ }^{14} \mathrm{C}$ activities decrease from the west to the east according to the dilution of the waste plume of the plant. Estimations of $\mathrm{CO}_{2}$ and ${ }^{14} \mathrm{C}$ flux show that a minor part of the ${ }^{14} \mathrm{C}$ liquid release by industrial activity is recycled to the atmosphere. These estimates are not very accurate due to the variation of $\mathrm{CO}_{2}$ transfer coefficients propose by different models. However, the ${ }^{14} \mathrm{C}$ releases in Bay of Seine could provide a good opportunity to perform new experiments in order to get better estimates of $\mathrm{CO}_{2}$ transfer coefficients between water and atmosphere.

\section{Acknowledgements}

The authors thank Messrs Le Bar and Schgier, Mrs Fitamant and her team at COGEMA for helping us during these campaigns. We also thank Messrs Le Bourhis and Henri, captains of the CNRS oceanographic vessel "Côtes de La Manche" and their crews. 


\section{References}

[1] COGEMA., Surveillance trimestrielle de l'environnement de la Hague. Rapport Hag. 055000120013 (2000), 84p.

[2] Fontugne M, Maro D, Baron Y, Hatté C, Hébert D, Douville E. Source and distribution of radiocarbon in the vicinity of La Hague nuclear reprocessing plant: Part I Terrestrial environment. Radiocarbon 46 (2004), 826-830.

[3] Fontugne M., Maro D., Baron Y., Hatté C., Hébert D. and Douville E., Identification of sources and distribution of radiocarbon in the vicinity of La Hague nuclear reprocessing plant, Radioprotection 37, C1 (2002) 1271-1276.

[4] Copin-Montégut G, 1996. Chimie de l'eau de mer. Institut Océanographique, Paris: 319p.

[5] Boehme SE, Sabine CL, Reimers CE. 1998. $\mathrm{CO}_{2}$ fluxes from a coastal transect : a time-series approach. Marine chemistry 63: 49-67.

[6] Frankignoulle M, Borges AV. 2001. European continental shelf as a significant sink for atmospheric carbon dioxide. Global biogeochemical cycles 15 (3): 569-76.

[7] Keir RS, Rehder G, Frankignoulle M.,2001. Partial pressure and air-sea flux of $\mathrm{CO}_{2}$ in the Northeast Atlantic during September 1995. Deep Sea Research Part II: Topical Studies in Oceanography, 48, (14-15): 3179-89.

[8] Liss PS, Merlivat L. 1986. Air-sea exchange rates: introduction and synthesis. In: The Role of AirSea exchange in Geochemical Cycling, P. Buat-Ménard (ed.), D. Reidel: 113-27.

[9] Tans PP, Fung IY, Takahashi T.,1990. Observational Constraints on the Global Atmospheric $\mathrm{CO}_{2}$ Budget. Science 247: 1431-38.

[10] Wanninkhof R, McGillis WR. 1999. A cubic relationship between air-sea $\mathrm{CO}_{2}$ exchange and wind speed. Geophys. Res. Letters 26(13): 1889-92.

[11] Maro D, Crabol B, Germain. P, Baron Y, Hébert D, Bouisset P. 2002. A study of the near field atmospheric dispersion of emission at height: Comparison of Gaussian plume models (Doury, Pasquill-Briggs, Caire) with krypton- 85 measurements taken around La Hague nuclear reprocessing plant,. Radioprotection 37(C1): 1277-82.

[12] DOE, 1994. Handbook of methods for the analysis of the various parameters of the carbon dioxide system in sea water. Version 2, A. G. Dickson \& C. Goyet (eds). ORNL/CDIAC-74.

[13] Maro D, Fontugne M, Hatté C, Hebert D, Rozet M. Source and distribution of radiocarbon in the vicinity of La Hague nuclear reprocessing plant: Part II Marine environment. Radiocarbon 46 (2004), 831-839.

[14] Bard E, Arnold M, Ostlund HG, Maurice P, Monfray P, Duplessy JC. 1988. Penetration of bomb radiocarbon in the tropical Indian Ocean measured by means of accelerator mass spectrometry. Earth Planet. Sci. Lett., 87: 379-89.

[15] Leboucher V, Orr J, Jean-Baptiste P, Arnold M, Monfray P, Tisnerat-Laborde N, Poisson A, Duplessy JC. 1999 Oceanic Radiocarbon between Antarctica and south africa along WOCE section I6 at $30^{\circ} \mathrm{E}$. Radiocarbon $41: 51-73$.

[16] Savoye N, Aminot A, Tréguer P, Fontugne M, Naulet N, Kérouel R. 2003. Dynamics of particulate organic matter $\delta^{15} \mathrm{~N}$ and $\delta^{13} \mathrm{C}$ during spring phytoplankton blooms in a microtidal ecosystem (Bay of Seine, France). Marine Ecology Progress Series 255: 27-41.

[17] Abril G. 1999. Dynamique du carbone dans les estuaires européens : processus de minéralisation et transfert continent-océan-atmosphère. Thèse de doctorat, Université de Bordeaux I: 173-209. 